\title{
WORKAHOLISM TYPES, PERFECTIONISM AND WORK OUTCOMES ${ }^{1}$
}

\author{
RONALD J. BURKE \\ Prof.Dr.,York University \\ RICHARD A. DAVIS \\ RHR International \\ GORDON L. FLETT \\ York University
}

\begin{abstract}
:
This study examined antecedents and consequences of workaholism among 327 women and men in a variety of professional and managerial jobs. Three workaholism types were considered (Work Enthusiasts, Work Addicts, Enthusiastic Addicts) using measures developed by Spence and Robbins (1992). Antecedents included a number of personal demographic and work situation characteristics, and measures of three aspects of perfectionism. Consequences included several validating job behaviors and work outcomes likely to be associated with workaholism. Although the three workaholism types were similar on personal and work situation characteristics, Work Addicts indicated greater perfectionism, more difficulty delegating tasks to others, less job satisfaction, and lower levels on three measures of work engagement than one or both of the other workaholism types. Interestingly, Work Addicts worked fewer hours per week than did Enthusiastic Addicts.
\end{abstract}

Key Words: Work Enthusiasts, Workaholism, Work Outcomes, Work, Managerial Jobs

\footnotetext{
1 This research was supported in part by the Schulich School of Business, York University, Hazell and Associates and the Department of Psychology, York University. Lisa Fiksenbaum contributed to the analysis of the data.
} 


\section{INTRODUCTION}

Although the popular press has paid considerable attention to workaholism (Fassel, 1990; Garfield, 1987; Kiechel, 1989a, b; Killinger, 1991; Klaft \& Kleiner, 1988; Machlowitz, 1980; Waddell, 1993) very little research has been undertaken to further our understanding of it. Most writing has been anecdotal and clinical (Fassel, 1990; Killinger, 1991; Oates, 1971; Schaef \& Fassel, 1988). The vast majority of workaholics were assumed to be men. Basic questions of definition have not been addressed and measurement concerns have been avoided (Scott, Moore \& Miceli, 1997).

It should come as no surprise then that opinions, observations, and conclusions about workaholism are both varied and conflicting. Some writers view workaholism positively from an organizational perspective (Korn, Pratt \& Lambrou, 1987; Machlowitz, 1980; Sprankle \& Ebel, 1987). Machlowitz (1980) conducted a qualitative interview study of 100 workaholics and found them to be very satisfied and productive. Others view workaholism negatively (Killinger, 1991; Schaef \& Fassel, 1988; Oates, 1971). These writers equate workaholism with other addictions, and depict workaholics as unhappy, obsessive, tragic figures who are not performing their jobs well and are creating difficulties for their co-workers (Naughton, 1987; Oates, 1971; Porter, 1996). The former would advocate the encouragement of workaholism; the latter would discourage it.

Some researchers have proposed the existence of different types of workaholic behavior patterns, each having potentially different antecedents and associations with job performance, work and life outcomes (Naughton, 1987; Scott, Moore \& Miceli, 1997; Spence \& Robbins, 1992). Naughton (1987) presents a typology of workaholism based on dimensions of career commitment and obsession-compulsion, identifying four types of workaholics. Scott, Moore and Miceli (1997) propose three types of workaholic behavior patters: compulsivedependent, perfectionist and achievement-oriented. Spence and Robbins (1992) identify three workaholic patterns based on their "workaholic triad" notion. The workaholic triad consists of three concepts: work involvement, driveness and work enjoyment. Workaholics score high on work involvement and driveness and low on work enjoyment. Work enthusiasts score high on work involvement and work enjoyment and low on driveness. Enthusiastic workaholics score high on all three components. 
A compelling case could be made for devoting more research attention to workaholism. The concept has received considerable attention in the popular press. There has also been suggestions that workaholism may be increasing in North America (Schor, 1991; Fassel, 1990). In addition, it is not clear whether workaholism has positive or negative organizational consequences (Machlowitz, 1980; Killinger, 1991). There is also debate on the association of workaholic behaviors with a variety of personal well-being indicators such as psychological and physical health and self-esteem. Different types of workaholic behavior patterns likely exist, each having unique antecedents and outcomes. The question of whether workaholism can, or should be reduced, had also been raised (Porter, 1996; Killinger, 1991; Seybold \& Salomone, 1994). Finally, it is important to study workaholism among women and examine possible gender differences in prevalence, antecedence and consequences.

A decision was made to use the definition of workaholism put forward by Spence and Robbins (1992) and their measures. Spence and Robbins (1992) define the workaholic as a person who "is highly work involved, feels compelled or driven to work because of inner pressures, and is low in enjoyment at work" (p. 62). Their definition was first academic/research definition and their measure was described in enough detail to assess reliability and validity issues, unlike most of the others (Machlowitz, 1980; Killinger, 1991).

This research also considers a number of potential consequences of workaholism identified in previous studies and literature reviews (Burke, 2000; Robinson, 1998; Scott, Moore \& Miceli, 1997; Spence \& Robbins, 1992). These include validating job behaviors such as perfectionism and hours worked, work outcomes such as job satisfaction and engagement.

Several writers have begun to explore the question of why managers fail (Dotlich \& Cairo, 2003; Kellerman, 2004;Hogan \& Hogan, 2001). Managers that fail have been shown to be bright, hard working, possess considerable business skill, and have lots of relevant work experience(Finkelstein, 2003). Instead, managers fail because of personality and character flaws that come to undermine their effectiveness and derail their careers (Kaplan, 1991) One such flaw that has been observed to limit the effectiveness of managers is perfectionism (Dotlich \& Cairo, 2003; Flett \& Hewitt, 2002; Hogan \& Hogan, 2001). Dotlich and Cairo (2003) characterize the perfectionistic manager as one who "gets the little things right and the big things wrong". Hogan and Hogan (2001) see the perfectionistic manager as 
obsessive-compulsive, inflexible, over-controlling and rigid. This investigation extends prior workaholism research by including several measures of perfectionism as well as a measure of job performance, making a link between work behaviors and performance that has no received attention previously.

\section{Method}

\section{Procedure}

Data were collected from 327 respondents using an internet based survey.

\section{Respondents}

Table 1 (Table 1) presents the demographic characteristics of the sample. Most respondents were female $(68 \%)$, worked full-time $(82 \%)$, were over 40 years old $(56 \%)$, had five or fewer years of job and organizational tenure $(62 \%$ and $55 \%$, respectively), worked between 31 and 50 hours per week (42\%) and earned between $\$ 51,000$ and $\$ 90,000$ per year of income $(49 \%)$.

\section{Measures}

\section{Personal and Work Situation Characteristics}

A number of personal demographic and work situation characteristics (e.g., age, gender, income, job tenure) were measured by single item measures.

\section{Workaholism Components}

Three workaholism componets proposed by Spence and Robbins (1992) were measured by scales they developed.

Work Involvement was measured by seven items $(\alpha=.75)$. One item was "I like to use my time constructively, both on and off the job".

Feeling driven to work was assessed by an eight item scale ( $\alpha=$ .84). An item was "I seem to have an inner compulsion to work hard, a feeling that it's something I have to do whether I want to or not". 
Joy in work was measured by ten items $(\alpha=.77)$. One item was "Most of the time my work is very pleasurable". Respondents indicated their agreement on a five point scale $(1=$ Strongly disagree, $3=$ Neither agree non disagree, $5=$ Strongly agree).

\section{Perfectionism}

Three aspects of perfectionism was measured using scales developed by Hewitt and Flett (1991) - the multi-dimensional Perfectionism Scale.

Self-Oriented Perfectionism (SOP) was measured by fifteen items $(\alpha=.91)$. One item was "When I am working on something. I cannot relax until it is perfect."

Other-Oriented Perfectionism (OOP) was assessed by fifteen items $(\alpha=.80)$. An item was "Everything that others do must be of top notch quality".

Socially Prescribed Perfectionism (SPP) was also measured by fifteen items $(\alpha=.89)$. "I find it difficult to meet others expectations of me."

\section{Difficulty delegating}

Difficulty in dealing work to others was measured by a seven item scale $(\alpha=.78)$ developed by Spence and Robbins (1992). One item was "l'd rather do tasks by myself instead of relying on others to help do the job".

\section{Engagement}

Three dimensions of work engagement were assessed by scales developed by Schaufeli, Salanova, Gonzalez-Roma \& Bakker (2002).

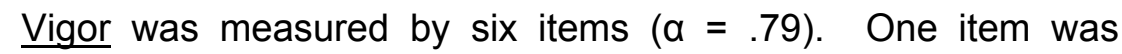
"When I get up in the morning, I feel like going to work".

Dedication was assessed by five items $(\alpha=.88)$. An item was "to me, my job is challenging". 
Absorption was measured by six items $(\alpha=.78)$. One item was "Time flies when I am working".

\section{Job Performance}

Self rated job performance was assessed by six items $(\alpha=.61)$. One item was "My performance on parts of this job could be better" (reversed).

Job satisfaction was measured by a five item scale $(\alpha=.85)$ developed by Quinn and Shepard (1974). One item was "All in all, low satisfied would you say you are with your job? $(1=$ Very satisfied, $4=$ Not at all satisfied).

\section{Results}

Workaholism Types

Six workaholism types were created (see Table 2) based on high or low scores based on the mean value of each of the three workaholism components. Table 3 shows the number of respondents falling into each type.

\section{Workaholism Type and Demographic Characteristics}

The six workaholism types were compared using one-way ANOVA; when the overall $F$ value was statistically significant $(p<.05)$, all pairwise comparisons were undertaken. The six workaholism types were first compared on eight personal demographic and work situation characteristics (see Table 4). Significant type effects were present on three: age, income and hours worked. WEs were significantly older than both WAs and DWs. WEs earned more income than did WAs. EAs worked more hours per week than WAs, UWs and RWs. The types were similar on number of direct reports, job and organizational tenure, work status and gender.

\section{Workaholism Types and Perfectionism}

Table 5 presents the comparisons of the workaholism types on three measures of perfectionism. Significant overall type effects were found on all three perfectionism measures. First, WAs scored higher on SOP than WEs, UWs and RWs; EAs scored higher on SOP than WEs, 
UWs and RWs. Second, WAs scored higher on SPP than WEs, UWs and RWs; and DWs scored higher on SPP than WEs and RWs. Third, both WAs and EAs scored higher on OOP than were RWs.

\section{Workaholism Types and Engagement}

Table 6 shows the comparisons of the workaholism types on the three engagement measures. Significant type effects were present on all three. First, both WEs and EAs scored higher on vigor than WAs, UWs, and DWs; RWs scored higher on vigor than WAs, UWs and DWs. Second, both WEs and EAs scored higher on Dedication than WAs, UWs and DWs; RWs socred higher on Dedication than WAs, UWs and DWs. Third, EAs scored higher on Absorption than WAs. UWs and DWs; WEs scored higher on Absorption than UWs; WAs scored higher on Absorption than did UWs and RWs scored higher on Absorption than UWs.

\section{Workaholism Types and Work Outcomes}

Table 7 compares the workaholism types on three work behaviors and outcomes; difficulty delegating, job satisfaction and selfrated job performance. First, there were no overall effects of workaholism type on self-rated job performance. Second, WAs reported more difficulty delegating than both WEs and RWs. Third, WEs indicated more job satisfaction than did WAs, UWs and DWs; EAs were more job satisfied than WAs, DWs; and RWs were more job satisfied than WAs, UWs, and DWs.

\section{Discussion}

This investigation replicated previous research on workaholism types as well as extended our understanding of these by including new variables. The findings were consistent with previous conclusions in many areas. First, the three workaholism types were similar on most personal demographic and work situation characteristics (see Table 4). Second, although the measures of perfectionism used here were more differentiated than the ones used in previous research, WEs were less perfectionistic than were WAs and EAs on two of the three measures of perfectionism. Third, WAs had more difficulty delegating than did WEs. Fourth, WAs were less job satisfied than the two other workaholism types. 
The new areas considered (engagement, self-rated job performance) produced interesting results. WAs indicated less engagement (lower vigor, dedication, absorption than one or both of the other workaholism types. WAs are more driven than WEs yet less engaged by their work.

There were no differences among the workaholism types on selfrated performance. This may have been due to the subjective nature of the measure raising the possibility of bias or the ambiguity of job performance evaluation criteria in many organizations.

The data comparing workaholism types on age, hours worked and income did not replicate findings reported previously. These significant differences (see Table 4) may reflect the sample that took part in the study. That is, previous studies employing a single or narrow sense of professions (e.g., psychologists, social work professors, MBA graduates in managerial and professional job) have shown no differences among workaholism types on these variables.

The picture that emerges is of a generally negative set of experiences being reported by WAs. These differences between the three workaholism types could not be explained by personal demographic characteristics, work situation characteristics or hours worked.

Possible explanations for the negative consequences reported by WAs lie in at least two areas. One resides in the personal beliefs and fears, the motivation behind the hours worked. Other research (Burke, 1999) has shown similar results. These findings resemble those reported for negative affect (Watson \& Pennebaker, 1989). In addition, Feeling driven to work, one of the three workaholism components in the Spence and Robbins (1992) measures, is strongly related to adverse health consequences.

The other promising area of exploration is in the job attitudes and behaviors likely to be exhibited by workaholics. WAs in this study reported greater perfectionism, more difficulty in delegating and less work engagement than did WEs. The pattern of these findings raises the issue of the performance contributions of WAs. That is, WAs are more likely to fare poorly because of these job behaviors. Future research should examine job performance using other indicators such as superior ratings and $360^{\circ}$ feedback assessments. 
Limitations of the Research

A few limitations of this research should be noted to put the results in context. First, all data were collected on the internet, in part using association membership lists, making a determination of the response rate difficult. It is also likely that the respondents do not constitute a random sample. Second, all data were collected using self-reports raising the possibility of response set biases. Third, given the nature of the sample, it is not clear the extent to which the results generalize to other samples. 


\section{References}

Burke, R.J. (1999) Workaholism in organizations: The role of beliefs and fears. Anxiety, stress and coping, 13, 1-12.

Burke, R.J. (2000) Workaholism in organizations: Psychological and physical well-being consequences. Stress Medicine, 16, 11-16.

Dotlich, D. L., \& Cairo, P. C. (2003) Why CEOs fail. San Francisco: Jossey-

Bass.

Fassel, D. (1990) Working ourselves to death: The high costs of workholism, the rewards of recovery. San Francisco, CA: Harper Collins.

Finkelstein, S. (2003) Why smart executives fail. New York: Portfolio

Flett, G. \& Hewitt, P. L. (2002) Perfectionism: Theory, research and treatment. Washington, DC: American Psychological Association.

Garfield, C.A. (1987) Peak performers: The new heroes of American business. New York: William Morrow.

Hewitt, P. L. \& Flett, G. L. (1991) Dimensions of perfectionism in unipolar depression. Journal of Abnormal Psychology, 100, 98-101.

Hogan, R., \& Hogan, J. (2001) Assessing leadership: A view from the dark side. International Journal of Selection and Assessment, 9, 40-51.

Kaplan, R.E. (1991) Beyond ambition: How driven managers can lead better and live better. San Francisco: Jossey-Bass.

Kellerman, B. (2004) Bad leadership. Boston: Harvard Business School Press.

Kiechel, W. (1989a) The workaholic generation, Fortune, April 10, 50-62.

Kiechel, W. (1989b) Workaholics anonymous. Fortune, August 14, 117-118.

Killinger, B. (1991) Workaholics: The respectable addicts. New York: Simon \& Schuster.

Klaft, R.P. \& Kleiner, B.H. (1988) Understanding workaholics. Business, 33, 37-40.

Korn, E.R., Pratt, G.J. \& Lambrou, P.T. (1987) Hyper-performance: The A.I.M. strategy for releasing your business potential. New York: John Wiley.

Machlowitz, M. (1980) Workaholics: Living with them, working with them. Reading, MA: Addison-Wesley.

Naughton, T.J. (1987) A conceptual view of workaholism and implications for career counseling and research. The Career Development Quarterly, 35, 180-187. 
Oates, W. (1971) Confessions of a workaholic: The facts about work addiction. New York: World.

Porter, G. (1996) Organizational impact of workaholism: Suggestions for researching the negative outcomes of excessive work. Journal of Occupational Health Psychology, 1, 70-84.

Quinn, R.P. \& Shepard, L.J. (1974) the 1972-73 Quality of Employment Survey, Ann Arbor, MI: Institute for Social Research, University of Michigan.

Robinson, B.E. (1998) Chained to the desk: A gudiebook for workaholics, their partners and children and the clinicians who treat them. New York: NYU Press.

Schaef, A.W. \& Fassel, D. (1988) The addictive organization. San Francisco, CA: Harper Row.

Schaufeli, W. B., Salanova, M., Gonzalez-Roma, V., \& Bakker, A. B. (2002) The measurement of engagement and burnout: $A$ confirmative analytic approach. Journal of Happiness Studies, 3, 71-92.

Schor, J.B. (1991) The Overworked American, New York: Basic books.

Scott, K.S. Moore, K.S., \& Miceli, M.P. (1997) An exploration of the meaning and consequences of workaholism. Human Relations, 50, 287-314.

Seybold, K.C., \& Salomone, P.R. (1994) Understanding workaholism: A view of causes and counseling approaches, Journal of Counseling and Development, 73, 4-9.

Spence, J.T. \& Robbins, A.S. (1992) Workaholism: Definition, measurement, and preliminary results. Journal of Personality Assessment, 58, 160178.

Sprankle, J.K. \& Ebel, H. (1987) The workaholic syndrome. New York: Walker Publishing.

Waddell, J.R. (1993) The grindstone. Supervision, 26, 11-13.

Watson, D. \& Pennebaker, J.W. (1989) Health complaints, stress and distress: Exploring the central role of negative affectivity. Psychological Review, 96, 234-254. 